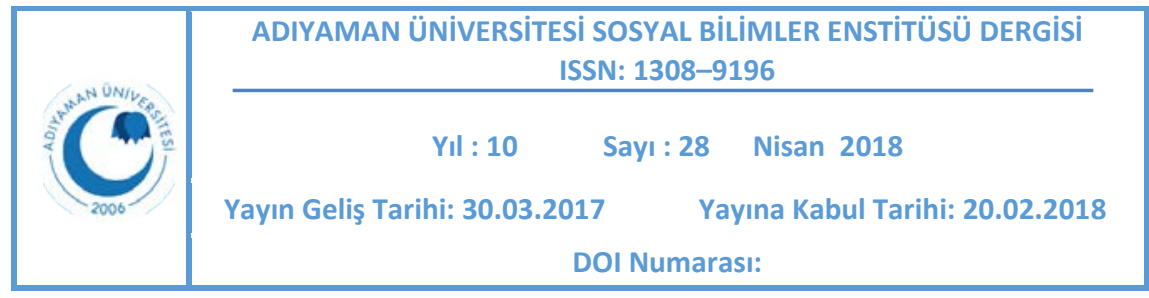

\title{
KUTADGU BiLIG'E GÖRE YÖNETICI VE NITELIKLERI
}

\author{
Büşra KOÇAK MACUN*
}

\author{
Yasemin KURTLU **
}

\begin{abstract}
$\ddot{O} z$
Sözlü veya yazılı edebî ürünler milletlerin zengin bilgi kaynaklarının başında gelmektedir. İslamiyet sonrası ilk Türk eserlerinden olan Kutadgu Bilig, Türk kültürü için bir ebedilik vasıtasıdır. Türklerdeki sosyal hayat, din, düşünüş, hükümdarlık anlayışı, devlet felsefesi... gibi daha birçok kültürel kodu bu eserde bulmak mümkündür. Kutadgu Bilig sayılan bu yönleriyle birlikte geçmişi bilmek, anlamak ve geleceğe yöntem önermek açısından da birçok bilimsel çalışmanın nesnesi olmuştur. Bu çalışmada amaç Kutadgu Bilig'in devlet yöneticisi açısından incelenmesidir. Çalışmada Kutadgu Bilig'in XII, XVII, XVIII, XXI, XXIII, XXIV, XXV, XXVI, $X X V I I, X L I, X L I I$ ve XLIII bölümleri hükümdar tasarımı ve devlet anlayışı bakımından incelenmiştir. Ancak ele alınan konuya göre eserin diğer bölümlerinden de yararlanılmıştır. Yönetici özelliklerinin sunulmasında eserden alıntılara yer verilmiştir. Kutadgu Bilig'de tasvir edilen hükümdar tipi bilgilidir, güçlüdür, savaşşıdır, siyaset bilgisiyle devletini en iyi şekilde idare ederek hem halkını mutlu eder hem de ülkesinin sınırlarını genişletir. Ancak Karahanlılar Devleti döneminde islamiyet'in kabul edilmiş olması nedeniyle hükümdar tasvirlerinde dinin etkisi de gözlenmektedir. Türk devlet ve hâkimiyet anlayışı dikkate alındığında hükümdar tipinin sahip olduğu özelliklerin aslında bir yöneticinin sahip olması beklenilen özellikler olduğu görülmektedir. Ancak Türklerde yerleşik hayata geçilmesi ile birlikte bozkır tipi alp tipinin yerini daha sistematik bir yönetim anlayışının aldığı görülmektedir.
\end{abstract}

Anahtar Kelimeler: Kutadgu Bilig, yönetici, devlet, nitelik, siyaset felsefesi, dil eğitimi, değer eğitim, halk kültürü.

\footnotetext{
${ }^{*}$ Arş. Grv. Ağrı İbrahim Çeçen Üniversitesi, Eğitim Fakültesi, bkocak@agri.edu.tr

** Öğretmen, MEB, y.kurtlu@windowslive.com
} 
MANAGER AND ITS QUALITIES ACCORDING TO

KUTADGU BILIG

\begin{abstract}
Verbal or written literary products are at the forefront of rich information sources of nations. Kutadgu Bilig, one of the first Turkish works after Islamism, is an eternal means for Turkish culture. It is possible to find social life, religion, thinking, government understanding, state philosophy and many other cultural codes of Turks. Kutadgu Bilig has become an object of many scientific studies in terms of knowing the past, understanding it and proposing a method to the future. From Kutadgu Bilig, it is possible to learn about Turkish administrators' understanding of state administration, power and politics. In this study, Kutadgu Bilig was examined in terms of the characteristics that a manager is expected to have in the context of "manager" and Turkish history and culture. In the study Kutadgu Bilig's sections XII, XVII, XVIII, XXI, XXIII, XXIV, XXV, XXVI, $X X V I I, X L I, X L I I$ and $X L I I I$ have been examined in terms of the design of the ruler and the understanding of the state. However, the other sections of the work were also utilized according to the subject discussed. Citations from the work have been included in the presentation of the manager features. In the study, the type of the ruler depicted in Kutadgu Bilig is knowledgeable, powerful, warrior, makes his people happy by expanding the boundaries of his country by managing his state with the knowledge of politics. However, due to the acceptance of Islam in the Karahanlilar State, the influence of religion in the depictions of the ruler is observed. Considering the concept of Turkish state and sovereignty, it is seen that the features possessed by the ruler are in fact the expected characteristics that a ruler should have. However, with the adoption of a sedentary life in the Turks, it is seen that the steppe type and the alp type are replaced by a more systematic management approach.
\end{abstract}

Keywords: Kutadgu Bilig, manager, state, quality.

\title{
1. GiRiş
}

Bir milletin geçmişine ışık tutan en önemli kanıtlar milletin kültür kodlarını yazıyla günümüze ulaştıran edebî eserleridir. Ortaya konulduğu dönemin dili, dini, kültürel ve sosyal yapısı, düşünüş tarzı, siyaset anlayışı kısaca döneminin zihniyetine ilişkin önemli bilgiler içeren edebî eserlerden geçmişi bilmek ve geleceğe yön vermek amacıyla yararlanmak bilinçli toplumların 
önceliklerindendir. Bu bağlamda Türk kültürünün İslami özellik kazanmaya başladığı ve geçmişle günün harmanlandığı geçiş döneminin ilk eserlerinden olan Kutadgu Bilig uyanık bilinçlerin dikkatine değerdir.

İlk özgün Türk eseri ve "Türk'ün Şahnamesi" olarak adlandırılan Kutadgu Bilig'in yazıldığı on birinci yüzyıl, Türk toplumunun yeni bir uygarlığı tanıma evresine girdiği bir dönemdir. Bir yandan eski Türk gelenekleri muhafaza edilmeye çalışılırken öte yandan da felsefe, bilim ve sanat hareketleri yeni bir insan tipini ön plana çıkarmaktadır. Ayrıca İslami yaşayış biçimi de toplumda hemen her alanda ağırlığını hissettirmekte ve zaman zaman İslami olmayan öğelerin toplum dışına itildiği görülmektedir. Kutadgu Bilig, ilk İslami eser olması dolayısıyla ilk Müslüman filozoflar ve onların kaynağı olan Batılı düşünürlerden Eflatun ve Aristo'nun görüşleri ve felsefeleri Yusuf Has Hâcib'e kaynak olmuştur. Batı'nın fikir ve görüşlerini alarak bunu İslami görüşlerle bağdaştıran Müslüman filozof Fârâbî'nin eserleri de devlet ve yönetim konusunda başvuru kaynağıdır (Akyüz, 2002).

Yusuf Has Hâcib Kitabın adını "Kutadgu Bilig koydum; okuyana kutlu olsun ve ona yol göstersin." (b. 350) açıklamasını yapmış ancak bu konuda farklı fikirler ortaya atılmıştır. Bilig bilgi anlamındadır. Kut+ad+gu= kutlu kılma anlamına gelir. M. F. Köprülü eserin adına saâdet veren bilgi derken, R. R. Arat ise kutlu ve mesut olma bilgisi demiştir (Kafesoğlu, 1980). Akyüz (2002) eserin adının birden çok anlamı olduğunu, kutluluk bilgisi, saadet bilgisi, devlet olma ve devleti idare etme bilgisi anlamlarında kullanılabileceğini söylemiştir. Kabaklı (2006) Türk Edebiyatı kitabında Kutadgu Bilig'in din, devlet, siyaset, terbiye, beyler ve halka ilişkin görüşlerin anlatıldı̆̆ı; nasihat, felsefe, din ve siyaset kitabı olduğunu söyler. Karşılıklı konuşma ve tartışma şeklinde düzenlenmiş olan eserde, sosyal ve siyasal düşünceler ileri sürülmekte ve öğütler verilmektedir. Bunları desteklemek amacıyla atasözlerine, o devrin büyüklerine ait vecizelere 
başvurulmaktadır (Caferoğlu, 2000: 56). Banarlı (2004: 235) eserin konusunun "Cemiyet halinde yaşayan insanları, maddi ve manevi bakımlardan mesut edecek yollar bulmaktır; bu yolları bir sosyal nizam içinde, bir hukuk prensibi, bir idare disiplini, bir dünya ve ahiret problemi halinde düşünmek; öyle sistemleştirmek ve bütün bunları hakanlara duyuracak görüşler ve öğütler halinde ifade etmek" olduğunu ifade etmiştir. Türk kültürü ve edebiyatının en önemli eserlerinden olan Kutadgu Bilig'de devlet ve yönetimle ilgili söylemin incelenmesi önemlidir.

Kutadgu Bilig, alegorik bir eserdir. Alegorik eserlerde verilmek istenen mesajlar semboller üzerinden okuyucuya taşınır. Her alegorik eser en az iki anlam katmanı taşır ve genellikle kahramanların isimlerinin çağrıştırdıkları, o alegorik eserin ikinci anlam katmanını oluşturur (Sinan Nizam, 2010). Kutadgu Bilig'de dört soyut kavram kişileştirilmiş ve Türk kozmolojisi de dikkate alınarak bu dört temsili karaktere uygun isimler verilmiştir. Bu kişiler ve temsil ettikleri kavramlar şunlardır: Kün Togdı (hükümdar) "gün doğdu, doğan güneş”, adaleti temsil eder. Ay Toldı (vezir) "ay doldu, dolunay", baht, talih ve ikbali temsil eder. Ögdülniş (vezirin oğlu) “övülmüş”, akıl ve anlayışı temsil eder. Odgurmış (vezirin kardeşi) "uyanık", dünya işlerinin sonunu temsil eder. Hükümdar Küntogdı, kendisine bu ismin verilmesini veziri Aytoldı'ya şöyle açıklar (Has Hâcib, 1985: 70- 71):

Âlim benim tabiatımı güneşe benzeterek bu adıverdi. Güneşe bak küçülmez, bütünlüğünü daima muhafaza eder; parlaklığı hep aynı şekilde kuvvetlidir. Benim tabiatım da ona benzer, doğruluk ile doludur ve hiçbir vakit eksilmez. Ikincisi, güneş doğar ve bu dünya aydınlanır; aydınlığını bütün halka eriştirir, kendinden bir şey eksilmez. Benim de hükmüm böyledir, ben ortadan kaybolmam; hareketim ve sözüm bütün halk için aynıdır. Üçüncüsü, bu güneş doğunca, yere sıcaklık gelir; o zaman binlerce renkli çiçekler açılır. Benim bu kanunum hangi memlekete erişirse, o memleket baştan başa taşlık ve kayalık dahi olsa, hep düzene girer. Güneş doğar, temiz veya kirli demeden, her şeye aydınlık verir; kendisinden bir şey eksilmez. Benim de hareketim tıpkı böyledir; herkes benden 
nasibini alır. Bir de güneşin burcu sabittir; bu sabit dediğim, temeli sağlam olduğu içindir. Güneşin burcu Arslan'dır ve bu burç yerinden kımıldamaz; yerinden kımıldamadığı için de evi bozulmaz. Benim tavır ve hareketime bir bak, benim de parlaklığım katiyen değişmez.

Yusuf Has Hâcib, Kutadgu Bilig'de Türk halkı arasında yaşayan ve yaygın olarak kullanılan motif ve kavramları edebî geleneğin gereğine uygun bir biçimde ifade etmiş ve eski Türk inanış ve mitinden de faydalanmıştır. "kün (güneş)" ve "ay" Türk mitolojisinde yeri olan kavramlardır. Eski Türk inanışlarında ay ve güneş ile ilgili inanışlar birlikte zikredilir. Türkler koruyuculuk vasfının Tanrı tarafından güneşe verildiği gibi kağanlara da verildiğine inandıklarından kağanlarını güneşle özdeşleştirmişlerdir. Ayla ilgili inanışlar güneşle ilgili inanışlara nispeten daha fazladır. Türk tasavvurunda Tanrı́nın göğün en üst katında bulunması, göğün bütün kâinatı kucaklaması, güneş, ay ve yıldızları katlarında bulundurması, göğün ululanması için kâfi sebeplerdendir. Güneş, ay ve yıldızlar da koruyucu iye mevkiindedir (Turan, 2011).

Kutadgu Bilig'de toplumu ilgilendiren konuların yanı sıra devlet anlayışına dair önemli bilgilere yer verilmiştir. Hükümdara yönetme hakkının Allah tarafından verildiğine inanılan kut inancından, kut'un kalıcı olabilmesi için kağanın yapması gereken işlere, hükümdarda bulunması gereken özelliklerden, devletleri uzun ömürlü kılan adalet anlayışı gibi birçok konudan bahsedilmektedir (Açık, 2016).

Yukarıda ifade edilen özellikleri nedeniyle Kutadgu Bilig'deki devlet yönetimi ve yöneticisi anlayışının incelenerek günümüz toplumunun dikkatine sunulmasının gerekli olduğu düşünülmüştür. Modern toplumların en önemli amaçlarından bir tanesi geçmiş ve gelecek arasında görünmez bağlar kuran maddi ve manevi kültür unsurlarının sonraki nesillere aktarılmasıdır. Edebî ürünlerin yazıldığı dönemlerin tarihi vesikası olması söz konusu değildir ancak içerikleri, iletileri ve dil özellikleriyle geçmişe ışık tutarak geleceğe yön vermeleri bakımından kültürel 
unsurların kalıcılığını sağlarlar. Bu bakımdan edebî metinlerin incelenmesi ve günün anlayışına göre yeniden yorumlanmasının hem halk kültürü çalışmalarına, hem edebî metin incelemelerine, hem de biricik kaynağı edebî metinler olan dil ve değer eğitimine kıymetli veriler sağlayacağı var sayılmıştır. Yine edebî metnin içeriğine göre elde edilen verilerin değerlendirilebileceği alanlar çeşitlendirilebilir. Kutadgu Bilig'in devlet yönetimi ve yöneticisine ilişkin iletileri içermesi bakımından, verilerin siyaset bilimi ve sosyoloji alanına da katkı sağlayacağı ön görülmektedir.

\subsection{Araştırmanın Amacı}

Bu çalışmada amaç Kutadgu Bilig'in devlet yöneticisi açısından incelenmesidir. $\mathrm{Bu}$ amaç doğrultusunda “Kutadgu Bilig'de ortaya konulan hükümdar tasarımı nasıldır? Kutadgu Bilig'de çerçevesi çizilen devlet yöneticisinin yönetimi nasıldır?" araştırma sorularına cevap aranmıştır.

\section{YÖNTEM}

Araştırmanın mahiyeti ve ana problemine uygun olarak nitel yaklaşım temelinde planlanan çalışmada amaca uygun örneklem yöntemiyle belirlenen Kutadgu Bilig'in XII, XVII, XVIII, XXI, XXIII, XXIV, XXV, XXVI, XXVII, XLI, XLII ve XLIII. bölümleri ele alınmış, hükümdar tasarımı bakımından incelenmiştir. Amaca uygun örneklem kullanımının temel sebebi ise araştırmanın ana amacında ifade edilen hükümdar tasarımı anahtar kavramıdır. Bu kavrama bağı olarak devlet yönetimi, adalet, devlet, bey, hükümdar, yönetici temaları araştırmanın veri analiz birimleridir. Eserde devlet anlayışı ve yönetici özelliklerini içeren bölümler amaçlı olarak seçilmiştir. Araştırmada veri toplama yöntemi olarak doküman incelemesinden yararlanılmış, araştırma verilerinin analizinde ise betimsel analiz tekniği kullanılmışıtr. 
Kutadgu Bilig iki farklı araştırmacı tarafından önceden gözden geçirilmiş ve analiz birimi olarak seçilen temalarla ilgili iletilerin olduğu bölümler ve birimler belirlenmiştir. Kutadgu Bilig'den seçilen XII, XVII, XVIII, XXI, XXIII, XXIV, XXV, XXVI, XXVII, XLI, XLII ve XLIII. bölümler iki farklı araştırmacı tarafından ayrı ayrı incelenmiş, analiz edilmiş ve sonrasında elde edilen veriler birleştirilip tutarlılıkları incelenerek sınıflandırılıp yorumlanmıştır.

\section{BULGULAR}

\subsection{Kutadgu Bilig'de Devlet Yöneticisinin Hâkimiyet Kaynağı}

Kutadgu Bilig'de devlet yöneticisinin sahip olması beklenen özelliklere değinilirken Türklerin cihan hâkimiyeti düşüncesine de sık sık vurgu yapıldığı görülmektedir. Eserin en belirgin özelliklerinden biri belki de İslamiyet öncesi Türk topluluklarında görülen bu anlayışın İslamiyet'in kabulünden sonra da devam etmesidir. Çünkü Türkler, devletin; milli varlığını koruyan, yaşatan ve geliştiren vazgeçilmez bir kurum olduğunun daima farkında ve bilincinde olmuşlardır. Türklerin ilk yazılı belgeleri niteliğindeki Orhun Kitabelerinde de Bilge Kağan Türklerin cihan hâkimiyeti ülküsünü dile getirmiştir:

Dokuz Oğuz beyleri, milleti! Bu sözümü iyice işit, adamakıllı dinle. Doğuda gün doğusuna, güneyde gün ortasına, batıda gün batısına, kuzeyde gece ortasına kadar, onun içindeki millet hep bana tabidir. Bunca milleti hep düzene soktum. O şimdi kötü değildir. Türk kağanı Ötüken ormanında oturursa ilde sıkıntı yoktur(Ergin, 2011: 3).

Yine İslamiyet sonrası Türk edebî ürünlerinden biri olan Divanü Lügat-it Türk'te de Türklerin cihan hâkimiyeti ülküsü ile ilgili şu ifadelere yer verilir (Kaşgarlı Mahmut, 1991'den akt. Kazmaz, 2000: 129):

Tanrı́nın devlet güneşini Türk burçlarında doğdurmuş olduğunu ve onların mülkleri üzerinde göklerin bütün teğrelerini döndürmüş 
bulunduğunu gördüm. Tanrı onalar Türk adını verdi ve onları yeryüzüne ilbay kıldı. Zamanımızın hakanlarını onlardan çıkardı; dünya milletlerinin idare yularını onların ellerine verdi; onları herkese üstün eyledi; kendilerini hak üzere kuvvetlendirdi. Onlarla birlikte çalışan onlardan yana olanları azi kıldı ve Türkler yüzünden onları her dileklerine eriştirdi; bu kimseleri kötülerin, ayak takımının şerrinden korudu.

Kutadgu Bilig'de ise cihan hâkimiyeti düşüncesi ile ilgili şu beyitlere rastlanmaktadır (Has Hacib, 1985, b.91, 93, 102, 103, 108, 2076):

Ey dünyanın süsü, ey ululuğun ziyneti, ey saltanatın nuru, ey dönek huylu saadetin bağını elinde tutan. Hakan tahta oturunca, dünya âsâyiş buldu; bundan dolayı dünya ona şâhâne hediyeler gönderdi.. Hakanın nâmı, sânı dünyaya yayıldı; onu göremeyen gözlerin uykusu kaçtı.. Dünya asayişe kavuştu ve nizam kuruldu; o adını kanunla yükseltti.. Ey iyi tabiatli ve asill nesepli hakan, dünya senden mahrum kalmasın.. Bütün dünya halkı ona kul olur; bu gibi beyler dünyaya hâkim olurlar ve bütün dileklerine kavuşurlar. *

Türk hâkimiyet anlayışında hâkimiyet yetkisi Tanrı tarafından verilmektedir. Yani siyasi iktidarının kaynağı, "kut" veren Tanrıdır ve hâkimiyetinin dayanağı ilahidir. Türk hükümdarı adeta Tanrı'nın yeryüzündeki temsilcisidir. Türklerdeki bu hâkimiyet anlayışı Asya Hun Devleti döneminden itibaren görülmektedir (Tuğral, 2008). Hunların kağanları bu kelimeyi "tengri kutı" şeklinde bizzat unvanlarında kullanmıştır (İnan, 1970). Hun hakanı Mete Han'ın unvanı da Tanrı'nın kutsadığı yiğit hükümdar anlamına gelen “Tanrıkut Bagatur Han”dır (Akyüz, 2002).

Eski Türklerde hâkim olan kut anlayışının izlerine Oğuz Kağan Destanı’nda da rastlamak mümkündür. Oğuz Kağan'ın yardımcısı olan Uluğ Türük gördüğü düşten sonra şu sözleri söyler (Banarlı, 1987: 20): “Ey Kağanım! Sana dirlik hoş olsun. Gök Tanrı düşümde ne verdiyse gerçek olsun. (Tanrı) bütün dünyayı senin nesline verdirsin." Oğuz Kağan oğullarına şöyle hitap eder: "Ey oğullarım! Ben çok yaşadım!....Gök Tanrı'ya borcumu ödedim. Sizlere de yurdumu veriyorum."

* Kutadgu Bilig metninden yapılan alıntılarda beyit numaraları esas alınmıştır. 
(Banarlı, 1987: 21). Oğuz Kağan'ın devlet idaresini (kut) Tanrı'dan bir emanet olarak kabul ettiği ve kendisinden sonra çocuklarına bıraktığı söylenebilir.

"Kut"un İslam'dan önceki manası ve ifade ettiği dini kült XI. asırdan sonra İslâm edebiyatında da pek çok yerde zikredilmiştir (İnan, 1970). Kutadgu Bilig'in isminde de bulunan "kutadgu" ibaresi de, kutadmak fiilinden yapılmış masdar olup, kut'a eriştirmek, kut sahibi kılmak demektir. Kut, Tanrı'nın vermiş olduğu bir lütuf ve keremdir. Kut ve kutluluk; halkın anlayışı ile bir devlet kuşu gibidir (Ögel, 1982).

Tanrı sadece siyasi iktidarı veren değil, aynı zamanda vermiş olduğu bu iktidarı geri alandır. Türk hükümdarları Tanrı́nın verdiği "kut” u ellerinde tutabilmek için devamlı çalışmak ve başarılı olmak zorundadır. Aksi takdirde kutlarını kaybederek iktidardan düşerler (Koca, 2002). Kut'un kalıcı olması, hükümdarın akıl, bilgi, iyi huy, alp ve cihangir olma, erdem sahibi olma, iyilik, güç, alçak gönüllü ve tatlı dilli olma, aşırı olmayıp kötü işlere girmeme, malını yerinde harcama, büyüğe saygı ve küçüğe sevgi gösterme, kimseyi kırmama, içki ve israftan uzak durarak dürüst olma gibi özelliklere sahip olmasına bağlıdır (Ögel, 1982).

Türklerin Müslüman olmasından sonra bu yeni inanç ve uygarlık anlayışı Türkleri siyasetten ekonomiye kadar birçok sahada etkilemiştir. Yönetim noktasında ise egemenlik sadece Tanrı'ya ait olup yönetici konumundaki kişilerin egemenliğe sahip olma konusunda her hangi bir üstünlüğü ya da hakları bulunmamaktadır. Yönetenler bizzat halkına hizmet etmek için yetkilendirilmiş kişilerdir. İslamiyet'e göre yöneticinin önemli bir konumu olmakla birlikte yönetme yetkisi dinsel yasalarla sınırlandırılmıştır ve kutsal yönetici ya da hanedan anlayışı yoktur. Yönetici olanlar mutlak ve sınırsız bir iktidara sahip olmayıp yaptığı bütün uygulamalarından dini kurallar çerçevesinde sorumludur. Türklerde, bu yeni inanışın etkisi ile birlikte eski anlayış ve gelenekler de varlığını sürdürmüş ve 
eski yeni etkileşimi egemenlik ve siyasal iktidara bakışta da kendisini göstermiş ve kurulan yeni Türk devletlerinin kuruluş ve iktidarında da etkili olmuştur. İslamiyet'in birincil kaynaklarında yer almamasına rağmen kutsal hanedan anlayışı ve karizması Müslüman Türk devletlerinin yönetiminde de etkili olmuştur (Özdemir, 2009). Kutadgu Bilig'de de o dönemde şekillenen bu anlayışın izleri görülmektedir.

Kutadgu Bilig'de İslami bir biçimde "kut" ifade edilmeye çalışılır. Egemenlik hakkı ve yönetme yetkisi "bey" e aittir. Bu hak ve yetki doğuştan kazanılmıştır ve kalıtsal olarak babadan oğula geçer. Beye üstünlük vasfı Tanrı tarafından verilmiştir (Akyüz, 2002). "Bu beylik mesnedine sen isteyerek gelmedin; onu Tanrı kendi fazlı ile sana ihsan etti. Lütuf ederek sana bu beyliği verdi; ey bilgisi geniş olan insan buna şükür et." (Has Hâcib, 1985: b. 5469, 5470).

\subsection{Kutadgu Bilig'de Devlet Yöneticisinin Sahip Olması Gereken Özellikler}

Yusuf Has Hâcib Kutadgu Bilig'de tasarladığı devlet yöneticisinin sahip olması gereken özelliklere yer vermiştir. Hâcib, devlet yöneticisi ile ilgili olarak ilk önce kut anlayışını ele alır (Has Hacib, 1985: b.1932, 1933, 1934, 1936):

Bey doğarken, beylikle doğar; görerek öğrenir ve böylece işlerin hangisinin daha iyi olduğunu bilir.. Tanrı kime bu beylik işini verirse, ona işi ile mütenâsip akıl ve gönül de verir.. Tanrı kimi bey olarak yaratmak isterse, ona önce münâsip tavır ve hareket ile akıl ve kol kanat verir.. Bu işi hükümdar benden daha iyi bilir; babası bey idi, kendisi de beydir.

Beyitlere göre bey doğulur, sonradan bey olunmaz. Dolayısıyla Tanrı, bey olacak kişiyi beyde olması gereken yeteneklerle donatmış olarak yaratmıştır ve babası bey olanın kendisi de beydir. "Türk Devlet Geleneği uyarınca, hâkimiyet hakkını Tanrı'dan alan ve böylelikle devletin basına geçen hükümdarın sahip olduğu ilk özellikte kendisinin bir payı yoktur. Çünkü bir hükümdarın oğlu veya kut ile 
donatılmış hanedanın bir erkek ferdi olarak dünyaya gelmiştir" (Tuğral, 2008:

86). Bu anlayış Kutadgu Bilig'de birçok yerde dile getirilmektedir.

\subsection{Beyin Fiziki Özellikleri ve Kişiliği}

Yusuf Has Hâcib, Kutadgu Bilig'de bir hükümdarın (bey) sahip olması gereken fiziki özelliklere de yer verir (Has Hacib, 1985: b.2083, 2084, 2085, 2086, 2087, 2089, 2090, 2310, 2311):

Bey güzel yüzlü, saçı sakalı düzgün, yakışıklı ve orta boylu olmalı.. Yüzünü gören herkes bakınca onu sevmeli.. Güzelliği bakan gözü sevgi ile parlatmalıdır.. Bilgi nazarında boyunun çok uzun olması makbul değildir; onun çok bodur olması da güzel düşmez.. Onun için bey orta boylu olmalıdır; orta boylu olması daha iyidir.. Kısa boylu, bodur kimseler hırçın tabiatlı olurlar, hırçın nereye giderse orada kavga başlar.. Boy orta ve her şey bununla mütenasip olmalı; ey bilgili insan her işte itidalden ayrılma.. Onun yüreği harpte arslan yüreği gibi ve dövüşürken de bileği kaplan pençesi gibi olmalıdır.. O domuz inatçı, kurt gibi kuvvetli, ayı gibi azılı ve yaban sığırı gibi kinci olmalıdır.

Kutadgu Bilig'de, bey özellikleri çeşitli hayvanlara atfedilmiş niteliklerle anlatılmıştır. Bu anlatım Oğuz Kağan Destanı'nda da görülmektedir. Beyin gücü kurt, inadı domuz, düşmanlığı sığır, korkusuzluğu aslana, dövüşmesi kaplana benzetilerek somutlamaya gidilmiştir. Eserde itidal vurgusu da önemlidir. Kutadgu Bilig'deki hükümdar anlayışına göre göre hükümdar orta boylu, güzel yüzlü, saçı- sakalı düzgün bir şekilde tasvir edilmektedir.

Bir hükümdarın sahip olması gereken karakter özelliklerine gelindiğinde ise ilk özelik asil bir soya sahip olmaktır. Eserde Öğdülmiş'in hükümdarın nasıl olması gerektiğini tarif ettiği bölümde "Beylik için ilk önce asil soydan gelmesi gerektir. Babası bey ise, oğul bey doğar; o da babaları gibi bey olur." (b. 1949, 1950) 
ifadeleri hem kut anlayışının hem de asil soydan gelmenin hükümdarda aranan nitelikler arasında olduğunu göstermektedir.

Yusuf Has Hâcib'in bir beyin sahip olması gerekenler arasında en sık vurguladığı özellikler akıllı ve bilgi sahibi olmaktır. Nitekim Küntogdı hakkında bilgi verirken önce bilgili olmasına değinmiş, akıllı olmasına da sıkça vurgu yapmıştır (Has Hacib, 1985: b.405, 408, 410, 1658, 1780, 1951, 1952, 1953, 1954, 1955, 1968, 1970, 1971, 1972, 3661):

Bu dünyada bir bey vardı, hakim ve bilgin bir baş idi.. O bilgili, akıllı, uyanık bir bey idi.. O böyle bir bey idi; işini bilgisi ile düzenledi.. Ögdilmiş cevap verdi :-Ey beyim, ey bilgi hazinesi, ey insanların iyisi - dedi.. Bey halkı bilgi ile elinde tutar; bilgisi olmazsa, aklı işe yaramaz.. Bey bilgili ve akıllı olmalıdır; cömert ve yumuşak huylu olmak da lâzımdır.. Beyler bilgi ile halka baş oldular ve akıl ile memleket ve halkın işini gördüler.. Bey adı bilig kelimesi ile ilgilidir; bilig'in lamı giderse, beg adı kalır.. Bey çok akıllı olmalı ve aklın kıymetini bilmelidir; bilgili insanın düşmanı çok olur.. Bilgiyi takdir eden, görmüş-geçirmiş ve çok gezmiş insan ne der, dinle.. Bilgisize devlet ve saadet gelirse, halkın arasına fesat girer ve bu, memleket için, öldürücü bir felâket olur.. Beylik hastalığının ilacı akıl ve bilgidir; ey yumuşak huylu, onu akıl ile tedavi et.. Bey, bilgili, akılı ve zeki olmalıdır; beyliğin hastalığına ancak bunlar ile çare bulunabilir.. Bilgili, akıllı ve hakim hükümdarın her iki dünyada da makamı yüksek olur.. Ey kul olan akıllı ve uyanık insan, ihmalkâr olma; dikkatli ol, başkasının yüzünden sana zarar gelmesin.

Bilgi akılla elde edilir ve akıl kullanılarak elde edilen bilgiler uygulamaya dökülür. Dolayısıyla hükümdar, her iki cihanda saadete ermek ve milletinin işlerini görebilmek için akıllı ve zeki olmalıdır.

Kutadgu Bilig'de hükümdarın iyilikten başka bir kasıtla konuşmamasına da vurgu yapılır. Hükümdar her halinde ve tavrında iyi olmalı ve iyi konuşmalıdır. Metinde 
Yusuf Has Hâcib bu düşüncelerini aşağıdaki gibi dile getirmiştir (Has Hacib, 1985:

b.1296, 1314, 1315, 1330, 1367, 1639, 1841):

Daima iyilik yap, kötülükten uzak dur; ister otur-ister kalk, bundan sana hep iyilik gelir.. Ey kuzum, iyilikten başka bir maksatla, ancak beylerin kullanabileceği sözleri ağzına alma. Başkasının zararını isteme, kendin de zarar verme; hep iyilik yap, kendi hava ve hevesine hâkim ol.. Saadete kavuşursan, kibirlenme; kötülük etme, elinden geldiği kadar iyilik yap.. Sen halkı belâdan-zulümden koru, iyilik yap; elinle ve dilinle onu sevindir.. Ey iyi insan, iyilik yapmakta devam et; iyilik ihtiyarlamaz, onun ömrü ebedîdir.. Her türlü iyilik akıldan gelir; insan bilgi ile büyür ve temayüz eder.

Kutadgu Bilig'de Türk hükümdarında aranan diğer bir özellik, beyin özü sözü dürüst olup, doğruluktan ayrılmaması ve yalana itibar etmemesidir. Hükümdar Küntogdı "tabiatı dürüst, tavrı munis idi; sözü doğru, gözü ve gönlü zengin idi. ..yüreği pek ve dürüst tabiatlı idi; bu tavrı ve hareketi onu günden güne yükseltti." (b. 407, 409). Eserde doğruluğa ilişkin aşağıdaki beyitlere yer verilmiştir (Has Hacib, 1985: b. 453, 771, 772, 800, 801, 802, 803, 804, 805, 806, $807,808,809,810,811,812,813,814,819,821,822,825,826,1316,2812)$ :

Ey yüzü sevinçle parlayan bahtiyar, insan dürüst hareket ederse, bu beylik ululuk çok iyi bir şeydir.. Bir gümüş taht üzerine oturmuştu; bu tahtın birbirine bağlanmamış üç ayağı vardı. Elinde büyük bir bıçak tutuyordu; solunda bir acı-ot ve sağında şeker bulunuyordu.. Işste bak, ben de doğruluk ve kanunum; kanunum vasıfları bunlardır, dikkat et. Bak, bu üzerinde oturduğum tahtın üç ayağı vardır; ey gönlümü doyuran. Üç ayak üzerinde olan hiç bir şey bir tarafa meyletmez; her üçü düz durdukça, taht sallanmaz. Eğer üç ayaktan biri yana yatarsa, diğer ikisi de kayar ve üzerinde oturan yuvarlanır. Üç ayaklı olan her şey doğru ve düz durur; eğer dört ayaklı olursa, biri eğri olabilir. Düz olan bir şeyin her tarafı, iyidir; her iyinin, dikkat edersen, tavır ve hareketi düzgündür. Hangi şey yana yatarsa, eğri olur; her eğrilikte bir kötülüğün tohumu vardır. Düz olan yana yatarsa, duramaz, düşer; hangi şey doğru ise, düşmez, yerinde durur. Bak, benim tabiatım de yana yatmaz, doğrudur; eğer doğru eğrilirse, kıyamet kopar. Ben işleri 
doğruluk ile hallederim; insanları, bey veya kul olarak, ayırmam. Ey becerikli insan, elimdeki bu bıçak biçen ve kesen bir âlettir. Ben işleri bıçak gibi keser, atarım; hak arayan kimsenin işini uzatmam. Şekere gelince, o zulme uğrayarak, benim kapıma gelen ve adaleti bende bulan insan içindir. $O$ insan benden şeker gibi tatlı-tatlı ayrılır; sevinir ve yüzü güler. Zehir gibi acı olan bu Hind otunu ise, zorbalar ve doğruluktan kaçan kimseler içer.. Bu beyliğin temeli doğruluktur; beyler doğru olursa, dünya huzura kavuşur.. Beyliğin temeli doğruluk üzerine kurulmuştur; doğruluk yolu beyliğin esâsıdır. Bey doğru olur ve ülkeye böyle hüküm ederse, bütün dileklerine kavuşur.. Güneşe bak, küçülmez, bütünlüğünü dâima muhafaza eder; parlaklığı hep aynı şekilde kuvvetlidir. Benim tabiatım da ona benzer, doğruluk ile doludur ve hiç bir vakit eksilmez.. Ağzından yalan söz çıkarma; yalan söz ile insan kendi itibarını düşürür. Beyler sözünde durmazlarsa itimadı kaybederler, itimat kaybolunca mal da gider.

Kutadgu Bilig'de hükümdarda doğruluğun bulunması gerektiği ve doğrulukla iyi olunabileceği ifade edilmektedir. Bir hükümdarın doğruluğunun güneş gibi olması gerektiği ve eksilip artmadan herkese aynı şekilde ve eşit olarak yansımasının gerekliliği vurgulanmaktadır. Doğruluğun adalet arayana adalet, zulme uğrayana hakkını verme, zorbalara gerekli yaptırımı uygulama gerektirdiği ve insanın millete eşit ve adil davranarak ancak doğru olunabileceği söylemleri dikkat çekicidir.

Kutadgu Bilig'de hükümdarın sahip olması istenen özellikler arasında zeki ve uyanık olmak da yer alır. Küntogdı için "O bilgili, akıllı ve uyanık bir beydi (Has Hacib, 1985: b.408)" ifadesi kullanılmaktadır. Ayrıca birçok beyitte de beyin zeki ve uyanık olmasına vurgu yapılmaktadır. "Ansızın bir iftiraya uğramaması için beyin bilgili, akıllı ve uyanık olması lazımdır.. Bey bilgili, akıllı ve zeki olmalıdır; beyliğin hastalığına ancak bunlarla çare bulunulabilir (Has Hacib, 1985: b. 1956, 1971)." 
Yusuf Has Hâcib' e göre bir bey cömert olmalı dünya malına tamah etmemelidir. Aynı zamanda kendisine verilene şükretmeyi bilmelidir (Has Hacib, 1985: b.756, 757, 1028, 1029, 1030, 1033, 1192, 1402, 1964, 2049, 2050, 5220, 5356, 5358):

Ey nimet sahibi olan muktedir kimse, şükret; şükredersen Tanrı nimetini artırır. Bu nimet sahibi çok defa kendisini unutur; fakat şükrederse nimet ondan yüz çevirmez.. Insanların itibarsızı geveze olanıdır; insanların itibarlısı cömert olanıdır.. Hükümdar bu sözleri işitti ve sevindi; gözlerini göğe dikti, elini kaldırdı. Tanrıya şükür etti, onu çok övdü ve dedi: Ey rabbim sen merhametli ve azizsin.. Bu ihsanlara şükürden ben acizim; ey asil, bunun şükrünü sana karşı yine sen eda et. Sözlerini burada kesti, hazinelerini açtı; fakirfukaraya çok mal dağıttı.. Malını insanlara dağıt, yedir ve içir; mal seni kullanacağına sen onu kullan.. Ey hükümdar, hasis olma cömert ol, cömert; cömertliğin adı ebedi kalır, ölmez.. Bilgili, akıllı, halka muamelesi iyi, cömert, gözü tok ve gönlü zengin olmalıdır.. Beye cömertlik ve alçak gönüllülük lâzımdır; alçak gönllülük ile birlikte tabiatı da sakin olmalıdır. Beyler cömert olursa, adları dünyaya yayılır; bunların nâm ve şöhreti üç dünya korunur.. Cömert ol, halka mal dağıt ve yedir; beyler hasis olursa, adları kötüye çıkar.. Beyler dibi inci dolu bir denizdir, denize yakın duran zenginleşmelidir.. Bey insanlara faydalı ve cömert olmalı, dünya halkına ondan tokluk gelmelidir.

Yusuf Has Hâcib'e göre bir bey nefsine hâkim olmalıdır. Zina, içki ve kumardan uzak durmalıdır (Has Hacib, 1985: b. 1334, 1337, 1338, 1375, 2091, 2093, 2097, 2013, 2106, 2107):

Şarap içme, fesada karışma, uzak dur; zina yapma, fısk ve fücur ile kara yüzlü olma.. Şarap içme, zina etme, kendini koru; ikisi de insana yoksulluk elbisesini giydirir. lçcki insanı bin türlü günaha teşvik eder; saadet zinadan kaçar ve zaninin yüzüne tükürür.. Bu dünya için kendini ateşe atma; vücuttan öcünü al, nefsin boynunu kopar.. Bey içki içmemeli ve fesatık yapmamalıdır; bu iki hareket yüzünden, sonunda ikbâl elden gider.. Dünyaya sahip olan vaktini kumara verirse, memleketin bozar ve kendisi de muhtaç duruma düşer.. Avam içkiye müptela oldu, malı rüzgâr gibi uçtu; bey içkiye müptela olursa, memleketi nasıl durur.. Bey içki içer ve oyunla vakit geçirirse, memleket işini düşünmeğe ne zaman fırsat bulur.. 
Bey içkiye müptela, müfsit ve kaba olursa, onun bütün halkı da ayyaş olur. Halkın bütün uygunsuzluklarını beyler düzeltir; bey uygunsuzluk ederse, onu kim yola getirir.

Türk devlet geleneğine göre bir bey, alçak gönüllü olmalıdır. Mağrur, kibirli, asık suratlı, küstah olmamalı; kabadayılık yapmamalıdır (Has Hacib, 1985: b. 703, $1330,1700,1702,1703,1706,2049,2073,2077,2078,2115,2118,2170)$ :

Beni bulan kimse mütevazi tabiatlı, alçak gönüllü ve tatlı dilli olmalıdır.. Saadete kavuşursan, kibirlenme; kötülük etme, elinden geldiği kadar iyilik yap.. Saadete alçak gönüllülük ne kadar uyar; alim bir insana hilm ve şefkat ne kadar yakışır.. Saadet gelip, kiminle bağdaşırsa, o kimse tevazu göstermeli ve alçak gönüllü olmalıdır. Saadet gelir ve insanın yüzüne gülerse, bil ki onun devamını sağlayan şey tevazudur.. Büyüklük taslayan, kibirli ve küstah adam tatsız ve sevimsiz olur; kibirli insanın itibarı günden güne azalır. Beye cömertlik ve alçak gönüllülük lâzımdır; alçak gönüllülük ile birlikte tabiatı da sakin olmalıdır.. Bey gönlünü alçak tutmalı, eli açık olmalı, merhameti de bunlarla mütenâsip bulunmalıdır.. Asık suratlı, kaba sözlü, kibirli ve mağrur insan her keşi kendisinden nefret ettirir ve işini yoluna koyamaz. Küstahlık, acelecilik, zevzeklik, bunlar avam tabiatıdır; bey bunlardan uzak bulunmalıdır.. Bey mağrur, kabadayı ve kibirli olmamalı; gurur insanı doğru yoldan çıkarır.. Beyler büyüklük taslar ve kibirli olurlarsa, ey oğul, onlar, şüphesiz, itibar görmezler.. O gözü tok, sabırlı, alçak gönüllü, şefkatli ve sakin tabiatlı olmalıdır.

Yusuf Has Hâcib'e göre Türk devlet geleneğinde bir bey inatçı olmamalıdır. "Ey kudretli devlet adamı, faydasız olan ve insana daima zarar veren şu üç şeydir. Biri kötü tabiatlı ve inatçı olmak, biri yalan söylemektir. Kim haşin tabiatlı ve inatçı olursa, onun işi her zaman ters gider (Has Hacib, 1985: b. 1667, 1668, 1670)."

İyi bir devlet adamı tatlı dilli ve güler yüzlü olmalıdır. İnsanlarla iyi iletişim kurabilmenin ve kendisini sevdirmenin yollarından biri de hiç şüphesiz tatlı dil ve güler yüzdür (Has Hacib, 1985: b. 547, 1311, 1415, 2072): 
Halk içinde kim nüfuz sahibi olursa, onun dili ve sözü tatlı olmalı, kendisi tevazu göstermelidir.. Hangi iş olursa olsun, sen onu tatlı dille karşıla; her işte tatlı dil kullanırsan saadet sana bağlanır.. insanlara kaba söz söyleme; kaba söz alev alev yanan bir ateştir.. O güler yüzlü, tatlı sözlü, yumuşak huylu olmalı ve bütün hareketlerinde de bunlara uygun davranmalıdır.

Yusuf Has Hâcib'e göre Türk devlet geleneğinde bir bey vefalı, insaniyetli ve iyi tabiatlı olmalıdır (Has Hacib, 1985: b. 1691, 1977, 1978, 1981):

Vefaya karşı vefa göstermek insanlık vazifesidir; vefakârlık et, insan ol ve adını yükselt.. Tabiatı iyi ve hareketi doğru ise, bak; o beyin hayatı sevinç içinde geçer. Tanrı kime bu iyi tabiatı ve bu iyi tabiat ile birlikte iyi gidişi kısmet ederse, bu dünya her türlü nimeti ile birlikte onun olur; isterse kendisi kullansın, isterse başkalarına dağıtsın.. II ve şehirleri idare, sulh ve sükûneti temin etmek için; hükümdarın iyi tabiat ve binlerce fazilete sahip olması lâzımdır.

Yusuf Has Hâcib'e göre bir Türk beyi takvalı, temiz kalpli ve hayâ sahibi olmalıdır. Beyin takva sahibi, temiz kalpli olması isabetli kararlar alabilmesinin de bir ölçütüdür (Has Hacib, 1985: b.1985, 1987, 2005, 2007, 2201):

Bey takva sahibi ve temiz olmalıdır; aslı temiz olan dâima temizlik ister.. Eğer bey takvâ sahibi ve temiz kalpli olmazsa; hiçbir vakit temiz ve isabetli hareket edemez.. Bey, hayâ sahibi ve insanların seçkini olmalı; hayâ sahibinin tavir ve hareketi eksilmeyen bir bütündür.. Tanrı kime hayâ ve iz'an vermişse; ona devlet ile birlikte bütün şerefleri vermiş demektir.. Insanların seçkini, hayâ sahibi olandır; hayâ sahibi olan kimse insanların başıdır.

\subsection{Beyin Yönetici Vasıfları (Adalet, Cesaret, İhtiyat, İyilik, Sabır)}

Kutadgu Bilig'de Küntogdı, törenin yani kanunların ve adaletin temsilcisidir. Onun adaleti de aynı güneşin ışıkları gibi her yere eşit dağılmalıdır. Hükümdar, zalim ve hasis olmamalı, boş yere kan dökmemelidir. Ayrıca hükümdar kanunları 
uygularken herkese eşit muamelede bulunmalı ve adaleti gerçekleştirmek isterken kimseye zulmetmemelidir (Has Hacib, 1985: b.454, 809, 817, 818, 827, $828,1433,1435,1451,1459,2017,2030,2034,2111,2136,2137,2168,2171$, $3462,3463,3464)$ :

Beylik çok iyi bir şeydir, fakat daha iyi olan kanundur ve onu doğru tatbik etmek lâzımdır.. Ben işleri doğruluk ile hallederim; insanları bey veya kul olarak ayırmam.. Ister oğlum, ister yakınım veya hısımım olsun; ister yolcu, geçici, ister misafir olsun; Kanun karşısında benim için bunların hepsi birdir; hüküm verirken, hiç biri beni farklı bulmaz.. Ikincisi - güneş doğar ve bu dünya aydınlanır; aydınlığını bütün halka eriştirir, kendinden bir şey eksilmez. Benim de hükmüm böyledir, ben ortadan kaybolmam: hareketim ve sözüm bütün halk için aynıdır.. Harama karışma, zulüm etme, insan kanı dökme, düşmanlık besleme ve kin gütme.. Eğer devamlı ve ebedî beylik istiyorsan, adaletten ayrılma ve halk üzerinden zulmü kaldır.. Adaletle iş gör, buna gayret et; hiç bir zaman zulüm etme; Tanrıya kulluk et ve onun kapısına yüz sür.. Ey hâkim devlet adamı, kötü teamül koyma; kötü kanunlarla dünyaya hükmedilmez.. Hangi bey memlekette doğru kanun koydu ise, o memleketini tanzim etmiş ve gününü aydınlatmıştır.. Zalim adam uzun müddet beyliğe sahip olamaz; zalimin zulmüne halk uzun müddet dayanamaz.. Kanun ile ülke genişler ve dünya düzene girer; zulüm ile ülke eksilir ve dünya bozulur.. Beyler örf ve kanuna nasıl riâyet ederlerse, halk da aynı şekilde örf ve kanuna itaat eder.. Her hangi bir bey halka kanun vermez, halkı korumaz ve halkın serveti kapanın elinde kalırsa; $O$, halkın içine ateş atmış olur, memleket bozulur ve hiç şüphesiz beyliğin temeli yıkılır.. Bey bilgili, akıllı ve adil olmalı.. Bütün faziletlerde herkesten üstün olmalı; halka karşı adaletle muamele etmelidir. Nerede adaleti ile şöhret bulan bir bey bulunursa, oraya gitmeli; insan onda saadetini bulur. Adalete istinat eden kanun - bu göğün direğidir; kanun bozulursa, gök yerinde duramaz. Bu kanun koyan beyler hayatta bulunmasalardı, Tanrı yedi kat yerin nizamını bozmuş olurdu.

Beyitlerde beyin örfe ve kanunlara uyması ve kanunları doğru tatbik etmesi gerektiği dile getirilmektedir. Düzenin adalete dayandığı, kanunun düzeni ayakta tuttuğunu ve Tanrı'nın yeryüzünde nizamı, adaleti sağlayan beylerle sağladığı 
ifade edilmektedir. Dolayısıyla Kutadgu Bilig'de hukuka dayalı bir devlet anlayışının olduğu, beyin ise adaletin uygulayıcısı olarak Tanrı'nın yerdeki temsilcisi olarak görüldüğü söylenebilir.

Yusuf Has Hâcib, Türk devlet geleneğinde "kut"un devam etmesini isteyen bir beyin doğru kanunlar koyarak adaleti tesis etmesi gerektiğini belirtmektedir. Kutadgu Bilig'de hükümdar Küntogdı, kendisine bu ismin verilme sebebini açıklarken adalet vasfını da belirtmektedir (Has Hacib, 1985: b.825, 826, 827, $828,829,830,831,832)$ :

Güneşe bak küçülmez, bütünlüğünü daima muhafaza eder; parlaklığı hep aynı şekilde kuvvetlidir. Benim tabiatım da ona benzer, doğruluk ile doludur ve hiçbir vakit eksilmez. Ikincisi, güneş doğar ve bu dünya aydınlanır; aydınlığını bütün halka eriştirir, kendinden bir şey eksilmez. Benim de hükmüm böyledir, ben ortadan kaybolmam; hareketim ve sözüm bütün halk için aynıdır. Üçüncüsü, bu güneş doğunca, yere sıcaklık gelir; o zaman binlerce renkli çiçekler açılır. Benim bu kanunum hangi memlekete erişirse, o memleket baştanbaşa taşlık ve kayalık dahi olsa, hep düzene girer. Güneş doğar, temiz veya kirli demeden, her şeye aydınlık verir; kendisinden bir şey eksilmez. Benim de hareketim tıpkı böyledir; herkes benden nasibini alır.

Metinde ebedi beyliğin kilit kavramı olarak adalet zikredilmektedir. Adaletle iş görme, halka zülüm etmeme, düzeni ayakta tutma adaletin tesis edilmesiyle mümkündür. Halka eşit davranma güneşe benzetilerek anlatılmış ve hükümdarın mahiyetindekilere eşit davranmasıyla güneşin her yeri eşit aydınlatması arasında bağ kurulmuştur. Dolayısıyla adil olma ve eşitlik düzenin devamı ve halkın mutluluğu için kağanda olması gereken nitelikler olarak verilmiştir.

Türk hükümdarlarda aranan en önemli özelliklerden biri de cesur, kuvvetli ve kahraman tabiatlı olmaktır. Nitekim Türk hükümdarları oturduğu yerden emirler 
vermez, gerekirse ordusuyla beraber savaşa gider, ön saflarda yer alır ve savaşır (Has Hacib, 1985: b. 1949, 1961, 2043, 2044, 2045, 2046, 2047, 2048):

Beylik için insanın ilk önce asîl soydan gelmesi gerektir; bey cesur, kahraman, kuvvetli ve pek yürekli olmalıdır.. Halk için beyin cesur ve kahraman olması iyidir; büyük işleri ancak bu meziyetler ile karşılamak mümkündür.. Bey cesur, kahraman ve atılgan olmali; bey cesareti ile düşmana karşı koyar. Korkak askerin cesaret alması için, kumandanın kahraman ve cesur olması lazımdır. Cesur insan korkakların başına geçer ve herkes ondan cesaret alır. Bu söze şahit olarak, şu beyti oku; bu sözü gönlüne al ve aklına koy. Arslan köpeklere baş olursa, köpeklerin her biri kendi karşısındakine aslan kesilir. Eğer aslanlara köpek baş olursa, o aslanların hepsi köpek gibi olur.

Bey güzel, orta boylu, adaletli, asil soydan gelen cesur bir kişi olmalıdır. Kağanın büyük işler yapabilmesi onun cesur olmasına bağlıdır. Cesur ve atılganlığıyla düşmana karşı koyabilen hakan, böylece askerlere iyi örnek olabilir. Cesur ve atılganlığıyla düşmana karşı koyabilen hakan, ordusuna da güç verir.

Yusuf Has Hâcib'e göre hükümdar tedbirli ve ihtiyatlı olmalı ayrıca ülkesini yönetebilmek için siyaset bilgisine de sahip olmalıdır (Has Hacib, 1985: b.438, $439,440,446,2014,2016,2127,2128)$ :

Bak böyle tedbir ile memleketini idare etti; saadeti günden güne arttı ve yükseldi. Her yerde insana böyle tedbir ve ihtiyat lazımdır; beylik işinde ise daha fazla dikkatli olmalıdır. Devlet işindeki bu tedbir ve uyanıklık, devletin uzun müddet devamı için daima faydalı olmuştur.. Ey hükümdar, memleket arzu edersen ihtiyatı ol.. Bey çok ihtiyatı ve çok da uyanık olmalı; beyler ihmalkâr olurlarsa, bunun cezasını başkaları çeker.. Hangi bey ihtiyatı ise, o memleketini muhafaza eder; düşmana boyun eğdirir ve onu sımsıkı bağlar. Himmeti ile beraber bir de siyaset lazımdır; siyaset için de beylik şartlarını haiz bir beyin riyaseti lazımdır. Bey memleket ve kanunu siyaset ile düzene koyar; halk hareketini onun siyasetine bakarak tanzim eder. 
Kutadgu Bilig'e göre bir Türk hükümdarı devlet işlerinde aceleci olmamalı, sabırlı ve kararlı olmalıdır (Has Hacib, 1985: b. 588, 1310, 1317, 1318, 1319, 1321, $1322,5218,5219):$

Hiçbir işte acele etme, sabret, kendini tut; kul sabırlı olursa beylik mertebesini bulur.. Hiç bir işte acele etme, sabırlı ol, kendini tut; sabırlı insanlar arzularına erişirler.. Eğer öfkelenirsen, kendini tut, sabırlı ol; sabırlı insan sonunda sevince kavuşur. Sabreden insan ne der dinle; insan sabrederse bozulmuş işler düzelir. Insan sabrederse dileğine kavuşur; sabredip bekleyen avcı ak-kuş tutar.. Eğer devlet gider ve kapısı kapanırsa, insan sabretmeli; onun bütün işleri tekrar yoluna girer. Sabırlı ol, sabretmek er kişi işidir; insan sabrederse, göğe bile yol bulur.. ihsanda bulunurken, acele et ve çabuk ver; cezalandırmak ve dayak atmak hususunda teenni ile hareket et. Harekette aceleci ve sözde zevzek olma, sabırlı ol; sabırlı insana halîm derler.

Beyitlerde amaca, arzulara erişmede sabırlı olma tavsiye edilirken halka ihsanda bulunurken aceleci davranmak gerektiği, cezalandırma hususunda ise sabırlı olmanın gereği dile getirilmektedir.

Bir Türk hükümdarı öfkesine hâkim olmalı hiddetle karar vermemelidir. Hükümdar Küntogdı, “..tavrı munis idi.” (b.407). "Eğer öfkelenirsen, kendini tut, sabırlı ol... İşinde hiddetli olma, öfkene hâkim ol; beyler hiddetli olurlarsa, mülk ve saltanat haleldar olur (Has Hacib, 1985: b. 1317, 1414)." Kutadgu Bilig'de, bir hükümdarın merhametli ve yumuşak huylu olması beklenmektedir (Has Hacib, 1985: b 414, 1412, 1416, 2000, 2006, 2072, 2170, 3458, 5197, 5262):

Insan için himmet ve mürüvvet gerek; insanın kıymeti himmet ve mürüvvet ile ölçülür.. Halk koyun gibidir, bey onun çobanıdır; çoban koyunlara karşı merhametli olmalıdır.. Sakin, halim, selim ve yumuşak huylu ol ve böylelikle bütün iyiliklere elini uzat.. Bey tok gözlü, hayâ sahibi ve yumuşak tabiatlı olmalı, sözünde ve hareketinde açık ve vazıh davranmalıdır.. Hayâ sahibi kimse yumuşak tabiatlı olur; kendisine yakışmayan hiç bir işe el sürmez.. O, güler yüzlü, tatlı sözlü, yumuşak huylu olmalı ve bütün 
hareketlerinde de bunlara uygun davranmalıdır.)Bey gönlünü alçak tutmalı, eli açık olmalı, merhameti de bunlarla mütenasip bulunmalıdır.. O gözü tok, sabırlı, alçak gönüllü, şefkatli ve sakin tabiatlı olmalıdır.. Hükümdar çok iyi bir padişahtır; çok merhametli, halkın candan sevdiği bir insandır.. Bütün halka karşı merhametli ol; büyüğe-küçüğe doğruluk ile hüküm et.. Bütün insanlara karşı merhametli ol; başkalarının zararını isteme, yolunu şaşırma.

Kağan halkın başındaki çobana benzetilmekte ve merhametle halka muamele etmesi istenmektedir. Yumuşak huylu olanların kendilerine yakışmayacak işler yapmadıkları ve hayâ sahibi yumuşak huyluluğun beylerin tabiatı olması gerektiği dile getirilmektedir.

Bir bey, siyaset icra ederken kendi şahsi meyillerini düşünmemelidir. Hükümdar

Küntogdı, "Siyaset icra ederken, kendi şahsi meyillerini düşünmez idi.. Beylik çok iyi bir şeydir fakat daha iyi olan kanundur ve onu doğru tatbik etmek lazımdır (Has Hacib, 1985: b. 411, 454)."

Türk hükümdarlarının asıl gayesi halkın refahı ve mutluluğu olmuştur. Büyük Türk hükümdarı Bilge Kağan, Orhun Abideleri'nde bu gayeyi vurgulamıştır: "Tanrı buyurduğu için, kendim devletli (kutlu) olduğum için, kağan oturdum. Kağan oturup, aç milleti doyurdum, çıplak milleti giydirdim, fakir milleti zengin, az milleti çok kıldım (Ergin, 2011: 7)."

\subsection{Beyin Yönetici Olarak Sorumlulukları}

Yusuf Has Hâcib bir beyin halkın refah ve mutluluğu için yapması gerekenleri şöyle ifade eder (Has Hacib, 1985: b. 2938, 5165, 5241,5242, 5243, 5244, 5245, $5302,5353,5358,5513,5536,5537)$ :

Ey huzur içinde yaşayan bey, buna fazla sevinme; sonunda huzuru zahmet takip eder.. Memlekette bir kimse bir gece aç kalırsa, onu 
Tanrı sana soracaktır; gözünü aç.. Ey hükümdar, sen bugün bir hekimsin; halkın ise, sana muhtaç olmanın hastasıdır. Bazısı darlığa düşmüştür ve bedbahttır; bir kısmı da fakirlik ızdırâbı içindedir. Bazısı aç, bazısı da çıplaktır; bazısı ise endişe içinde kıvranır. Bütün bunların devâsı sendedir; sen onların hekimi ol, ilaç ver ve tedavi et. Eğer sen bunlara, ilaç vererek tedavi etmezsen; halk için bir hayat felaketi olursun.. Fakir, dul ve yetimleri kolla; bunları korumak, kanunu gerçekten tatbik etmek demektir.. Kendi menfaatini arama, halkın menfaatini düşün; senin menfaatin halkın menfaati içindedir.. Bey insanlara faydalı ve cömert olmalı, dünya halkına ondan tokluk gelmelidir.. Birçok adamlar toplamalı ve onlara ihsanlarda bulunmalı; fakiri zenginleştirmeli ve açı doyurmalıdır.. Memleketin faydasını kendi menfaatin ile telif et; başkasının menfaatini düşünüp, ona bağlanma. Başkasının gönlüne bakma, herkes kendi istifadesini kollar; memleket menfaatini ara ve kendini zorla fena duruma düşürme.

Türk devlet anlayışında ordunun büyük önemi vardır. Türk devletleri yüzyıllarca eli silah tutan ve gerektiğinde ordusunun başında savaşa giden yöneticilerle yönetilmişlerdir. Yusuf Has Hâcib, bir beyin kumandanlık ve orduyu tanzim etme vasıflarını da vurgulamaktadır (Has Hacib, 1985: b. 2138, 2139, 2144, 2145, 3005, 3006, 3033, 5462, 5463):

Hangi bey askerini memnun etmezse, kılıç da kınından çıkmaz. Beyler kılıç ile memleketlerine hâkim olurlar, kılıçsız, gafil bey, memleketine sahip olamaz.. Kılıç kımıldadığı müddetçe düşman kımıldayamaz; kılıç kınına girerse, beyin huzuru kaçar.. Ey bey, kılıç kullananı her vakit memnun et ve böylece kendin de daima sevinç içinde yasa ve zahmet yüzü görme.. Asker, beylerin kanat tüyüdür; ey beyler-beyi, kanatsız kuş uçamaz. Beylerin kuvvet ve kudreti asker ile belli olur; beyler asker ile dügüümleri çözerler.. Asker beyden memnun oldu mu, bey hangi memleketi isterse, onu elinde bulur.. Hazine ve ordu beylerin kuvvetini teşkil eder; bu ikisi ile insan kendi öcünü alır. Bu ikisi ile bey büyüklük bulur; bu ikisi bir araya gelirse, beylik tacı azamet kazanır.

Yusuf Has Hâcib, devletin bekası ve saadetin devamı için devletin her kademesinde sadık, seçkin ve liyakatli kimselere görev vermenin, beyin mühim 
vazifelerinden biri olduğunu vurgular. Kutadgu Bilig'de hükümdar Küntogdı, kendisine yardımcı ararken şu özelliklere dikkat eder (Has Hacib, 1985:b.423, $424,425,426,427,428,429,430,1759,1760,2571,2574,2768,3127)$ :

Bana şimdi seçkin akıllı, bilgili ve maharetli bir adam lazımdır. $O$ bana candan bağlı, emniyetli, doğru ve dürüst yaradılışlı, içi-dışı bir ve işten anlar bikrimse olmalıdır. Memleketin iç ve dış işlerini takip hususunda bana yardımda bulunmalıdır. Tecrübeli, başından çok iş geçmiş ve yaşını başını almış insan ne der dinle. Insana yardım eden ve destek olan akıllı, bilgili ve hâkim idare adamları lazımdır. Bütün işleri bilir bir yardımcı lazımdır; insan bilerek hareket ederse, dileğine erişir. Yardımcı çok olursa, bey zahmet çekmez; onun her işi yoluna girer ve nizam bozulmaz. Bil ki, her işte yardımcı gerektir; beylik işinde ise, kendine daha çok yardımcı edinmeğe bak.. Ey bey, işi işin ehline, işe yarayana, hareketi doğru ve dürüst olana ver. Eğer bir bey işi ehliyetsiz bir kimseye verirse, ehliyetsizliği başkası değil, kendi göstermiş olur.. Candan hizmet eden sadık ve candan bağlı bir kulun hizmeti beyliğin temelini günden güne sağlamlaştırır.. Candan bağlı hizmetkârın kıymeti, merhametsiz ve hayırsız evlattan, daha yüksektir.. içten bağlı kimse insanların seçkinidir; içten bağlı olan kimseyi sıkı tut, ey insanların ileri geleni.. Beyler arayıp, sadık bir kul bulurlarsa; onu altın ve gümüş mahfaza içinde tutmalıdırlar.

Beylerin etrafında onların işlerini kolaylaştıracak yardımcıların bulunması gerektiği ifade edilmektedir. Bilgili ve akıllı olan bu kişiler hükümdarın devleti yönetmesine yardımcı olmaktadırlar. Buna göre devlet tek kişi tarafından yönetilmemekte ve hâkimiyet tek kişiye bağlı olmamaktadır.

Yusuf Has Hâcib'e göre hükümdarın diğer bir önemli görevi de, âlimleri koruyup kollamak ve onların sıkıntılarını gidermektedir. Çünkü âlimler insanı devlet ve saadete ulaştıran kişilerdir (Has Hacib, 1985: b.265, 268, 4343, 4344):

Bak, iki türlü insan vardır; biri-bey, biri-âlim; bunlar insanların başıdır.. Biri eline kılıç aldı, halkı itaat altında tutar; biri eline kalem aldı, doğru yolu bulup gösterir.. Faydalı ve zararlı şeyleri birbirinden ayırt ederek, doğru ve temiz yol tutan kimseler 
bunlardır.. Mümkünse, ilimlerini öğren ve bilgilerini bil; onlara iyilik yap ve yardımda bulun; onlara dil uzatma.

Kutadgu Bilig'e göre yönetici devletin düzenini sağlama ve kötülükleri cezasız bırakamamakla sorumludur. Kutadgu Bilig'de hükümdarın gerçekleştirmesi beklenen bu vazife ile ilgili şu ifadelere yer verilmiştir (Has Hacib, 1985: b.5279, 5280, 5546, 5547, 5548):

Ey hükümdar, kılıç ve sopa sendedir; bu kamçılar, bu cezalar kötüler içindir.. Kötüler kötülüklerini bırakmadıkları nispette, sende cezalarını eksik etme, elinde sopan hazır bulunsun.. Şehir ve kasaba içinde hırsızı ortadan kaldır; yolcu ve kervan emniyet içinde sefer etsin.. Memleket içinde halka zulüm edenleri yok et, dış eyaletlerde de bir tane yol kesen şâki bırakma.. Kötüyü, ceza vererek doğru yola getir; kötüye kötü muâmele lâyıktır, sende öyle yap. Türk devlet geleneğinde, bir kağan, han ya da hükümdar fetihler yaparak ülkesinin sınırlarını genişletmekle yükümlüdür. Türk tarihi incelendiğinde devlet başına gelen isimlerin büyük çoğunluğunun fetihlerle ömür geçirdiği görülür. On birinci yüzyılda İslamiyet'in kabulüyle birlikte cihat düşüncesi hâkim olmaya başlamıştır. Yani artık amaç sadece yeni topraklar fethetmek değil fethedilen yerlere İslamiyet'i de yaymaktır. Yusuf Has Hâcib Karahanlılar Devleti döneminde yaşamıştır. Karahanlılar İslamiyet'i kabul eden ilk Türk devleti olma özelliği taşımaktadır. Bu nedenle Yusuf Has Hâcib’in Kutadgu Bilig'de hükümdara cihat yapma görevini yüklediği görülmektedir. Böylelikle on birinci yüzyıldan itibaren Türklerin cihan hâkimiyeti idealine İslamiyet'i yayma amacı da eklenmiş olur. Kutadgu Bilig'de hükümdarın bu özelliği şöyle ifade edilir (Has Hacib, 1985: b. $5484,5485,5486,5487,5488)$ :

Asker ve ordu ile bu düşman kâfirini ez; gönül temizliği ile Tanrı'dan kuvvet ve tevfik dile.. Asker, ordu ve silahını kâfirlere çevir; kâfirler ile dövüşürken ölmek, ölüm değildir.. Onların evinibarkını yak, burkanını kır; yerine cami yap, etrafına İslam cemaati 
toplansın.. Oğlunu ve kızını esir ederek, kul ve câriye et; oradan aldığın servetle hazine kur.. İslamiyet'i aç, şeriatı yay; böylece seçkin bir şahsiyet olur ve iyi bir nam kazanırsın.

\section{SONUÇ VE TARTIŞMA}

İslamiyet sonrası Türk edebiyatının ilk örneklerinden Kutadgu Bilig İslamiyet öncesi Türk devlet yöneticisi anlayışı ile benzerlik göstermektedir. Kutadgu Bilig İslamiyet öncesi dönemde yöneticilerde olması beklenen özelliklerin İslami kavramlarla harmanlanarak dile getirildiği bir siyaset bildirgesi gibidir. Nitekim İslamiyet öncesi edebî eserlerden biri olan Oğuz Kağan Destanı Türk halkının ağzından idealleştirilen ama gerçekliği olan bir devlet adamının nasıl olması gerektiğine verilen bir cevap gibidir. "Oğuz Kağan, Türklerin çok eski dönemlerdeki hayata bakış tarzlarına ve inanç sistemlerine yönelik önemli ipuçları taşıyan edebî bir anlatıyı ve bu anlatının kahramanını temsil etmektedir (Keskin, 2012: 16)." Doğan (2002) Kutadgu Bilig'in Türk İslam devletinin temel felsefesini verme amacı güttüğünü dile getirmiş ve eserin çağdaş devlet anlayışının eleştirisi açısından kültürel bir kaynak olduğunu vurgulamıştır.

Kutadgu Bilig'deki hükümdar tasarımı ve devlet anlayışı ilk olarak hükümdarlığın kaynağı bakımından değerlendirilmiştir. Hükümdarlığın kaynağı Tanrı'dır ve Tanrı kime yönetimi bağışlar ya da nasip ederse yönetici o olur. Ayrıca hükümdarın asil bir soydan geldiği vurgusu yapılır. Alan yazındaki çalışmalarda da bu düşünce dile getirilmektedir. İlk Türk Devletlerinde hâkimiyetin kaynağı ilahi kaynağa dayandırımaktadır. Türk düşüncesine göre kutu yani siyasi otoriteyi Tanrı vermekte, başka bir ifadeyle hâkimiyet gökten alınmaktadır. Türk hükümdarlarına halkı idare etme hakkı Tanrı tarafından bağışlanmakta ve yarlık olarak düşünülmektedir (Karakaş, 1998). Türkler, iktidarın kaynağını Tanrı’ya atfederek hakanı Tanrı huzurunda sorumlu tutmuş ve insanları bir hükümdarın şahsî insaf duygusuna sığınmaktan kurtarmışlardır (Öz, 2011). 
Kutadgu Bilig bir hükümdarın sahip olması gereken özellikler açısından bilgi vermektedir. Beyin fizikî özellikleri hayvan teşbihleriyle anlatılmış ve bey güçlü, inatçı, korkusuz, itidal üzerinde bir kişilik olarak vurgulanmıştır. Eserde vurgulanan kişilik özelliklerinden bazıları şöyledir: Bey,

- Asil bir kişiliktir

- Güçlü, kuvvetli, itidalli ve kararlıdır.

- Akıllı, zeki, uyanık ve bilgi sahibi biridir.

- İyi birisidir ve güzel konuşur.

- Doğru, özü sözü bir kişidir.

- Cömerttir.

- Çok şükreder.

- Kötü alışkanlıkları (içki, kumar vb.) yoktur.

- Alçak gönüllüdür.

- Kibirli, küstah ve inatçı değildir.

- Tatlı dilli, güler yüzlüdür.

- Insaniyetlidir.

- Temiz kalpli ve hayâ sahibidir.

- Orta boylu, yakışıklı ve güzeldir.

Kutadgu Bilig'de yöneticilerde bulunması gereken özelliklerin günümüzde bireylerin sahip olması gereken ideal değerler olduğu söylenebilir. Beyin bilgili bir kişi olması Kutadgu Bilig'de önemle üzerinde durulan bir konudur. Fârâbî bilgiye ilişkin görüşlerini açıklarken üst düzey bilginin Faal Akıl'dan gelen bilgi olduğunu ifade etmekte ve yöneticilerde bulunması gereken ilk özelliğin faal Akıl ile ittisali olmasıyla açıklamaktadır (Aydınlı, 2004; Fârâbî, El-Medînetu'I Fâdıla, s. 104'ten akt, Kara, 2016). Dolayısıyla Kutadgu Bilig'in İslam felsefesinde yer verilen yönetici özelliklerini kendi döneminin diliyle ifade ettiği söylenebilir. 
Türklerde beyliğin Tanrı tarafından verildiği inancıyla birlikte hükümdarın bazı fiziksel ve ruhi özelliklerle donatıldığı düşünülür. Kutadgu Bilig'deki hükümdar tasvirinde, yöneticinin fiziksel güç ve güzelliğine değinilmiştir. Bir hükümdarın fiziksel olarak güzel ve güçlü olması vurgulanmıştır. Hükümdarların sahip olması gereken bir diğer niteliği cömertliktir. Kutadgu Bilig'de doğrudan hakanın cömert olması gerektiği söylenmektedir. Cömert olan hakan halkına yararlı olur. Böylece namı dünyaya yayılır ve iyilikle anılır. Kutadgu Bilig'de hükümdarın sabırlı olması gerektiği belirtilmektedir. Sabırla amaca erişileceği ve cezalandırma hususunda sabırlı olunması gerektiği, sabretmenin er kişinin işi olduğu söylenmekte ve kağana sabır tavsiye edilmektedir. Kutadgu Bilig'de merhamet ve yumuşak huyluluğun beylerin tabiatında olması gerektiği dile getirilmekte ve beylere yumuşak huyluluk ve merhamet tavsiye edilmektedir. Kutadgu Bilig'de beyin alçak gönüllü, sakin tabiatlı, halkıyla iletişiminin iyi ve her türlü faziletlere sahip olması gerektiği ifade edilmektedir. Bu faziletlere sahip olan beylerin hem dünya hem de ahiret saadetine sahip olacağı ifade edilmiştir. Beylerin takva sahibi, temiz, ihtiyatlı, uyanık ve güler yüzlü olması gerektiği Kutadgu Bilig'de vurgulanan kişilik özellikleridir ve bu özellikler devletin uzun ömürlü olması için elzemdir. Kutadgu Bilig'de beylerin asık suratlı, kibirli, küstah, aceleci, zevzek, fesat olmaması gerektiği, halka karşı büyüklenmenin itibarı düşüreceği ve içki içmenin devletin düzenini bozacağı dile getirilmektedir. Kutadgu Bilig'de kağanın sahip olması gerek bütün nitelikler İslam'ın gerektirdiği ahlak yapısıyla örtüşmesi, kağanın takva sahibi olması gerektiğinin ifade edilmesi, güçlü bir ahiret inancının vurgulanması ve iki cihan için çalışılmasının gerektiğinin söylenmesi kağanın dinini yaşayan biri olması gerektiğini ortaya koymaktadır. Hükümdarların sahip olması gereken bir diğer nitelik iyiliktir. Kutadgu Bilig'de doğruluk doğrudan ele alınmakta ve hükümdarın sahip olması gereken önemli nitelikler arasında yer verilmektedir. Doğru olan hükümdarın tahtı üç ayaklıdır. Çünkü üç ayaklı olan bir şey her hangi bir tarafa meyil edemez, 
ederse devrilir. Hakan da doğruluktan ayrılır bir tarafa meylederse hükümdarlığının sona ereceği mesajı verilmektedir. Alan-yazında yapılan birçok çalışmada benzer sonuçlara ulaşıldığı görülmektedir (Adalıoğlu, 2013; Açık, 2016; Büyükbaş ve Vargün, 2016).

Kutadgu Bilig'de özellikle yöneticinin fiziksel gücü ve özelliklerinin hayvan teşbihleriyle anlatılması İslam öncesi düşünce sisteminin bir yansıması olduğu söylenebilir. Kurtlu ve Koçak (2016) tarafından Oğuz Kağan Destanı üzerine yapılan çalışmada Oğuz Kağan'ın fiziki özelliklerinin hayvanların fiziki özelliklerine benzetilerek anlatıldığı belirtilmiştir. Maddelerde belirtilenlerin her insanda olması gereken değerler olduğu söylenebilir. Bu anlamada eserin değer eğitiminde kullanılabilirliği incelenebilir. Yine aynı erdemler siyaset felsefesi veya siyasetle ilgilenenlere yol işareti olabilir.

Kutadgu Bilig'de bir bey yönetici olarak adaletli, cesaretli, ihtiyatlı, sabırlı, kahraman ve iyilikte bulunan bir kişilik olarak resmedilmiştir. Sarıkaya (2014) "Kutadgu Bilig'e Göre Bey'in Özellikleri" başlıklı çalışmasında beyin affedici, cömert, sabırlı, vefakâr, faziletli, mütevazı, hayâ sahibi, kötü alışkanlıkları olmayan, tatlı sözlü ve doğru sözlü, ihtiyatlı, öfkesini kontrol edebilen, adil bir kişilik olarak Kutadgu Bilig'de tasvir edildiği sonucuna ulaşmıştır. Dolayısıyla bu çalışmanın sonuçlarının alan yazında yer alan sonuçlarla tutarlı olduğu söylenebilir.

Kutadgu Bilig'de bir yönetici olarak beyin sorumlulukları da sıralanmıştır:

- Halkın mutluluk ve refahını sağlamak

- Devletin ordusunu tanzim etme ve yönetme

- Devlet kademelerine liyakatli kişileri getirme

- Kendisine devlet yönetiminde yardımcı olacak danışmanlar edinme

- Mahiyetindeki âlimleri koruma ve ihtiyaçlarını görme 
- Devlet düzenini sağlama

- Adaleti tesis etme ve kötüleri cezalandırma

- Fetihler yaparak devlet sınırlarını genişletme

Yukarıdaki maddeler incelendiğinde devlet yöneticisi olarak beyin sorumluluklarının sosyal devlet anlayışına, cihan hâkimiyeti düşüncesine ve Türk devlet geleneğine uygun sorumluluklar olduğu söylenebilir. Öz (2011) tarafından “Kutadgu Bilig'de Türk Cihan Hâkimiyeti Düşüncesi” başlığıyla yapılan çalışmanın sonuçları da yukarıdaki ifadeleri doğrulamaktadır.

Kutadgu Bilig'de bahsedilen devlet hukuka dayalıdır ve kanunlarla yönetilmektedir. Nizamın adaleti tesis eden ve nizamı ayakta tutan kanunlarla oluştuğunu ve bunun beylerin görevi olduğu dile getirilmektedir. Beylerin de töreye ve kanunlara bağlı olduğu dolayısıyla beylerin sınırsız yetkilerinin bulunmadığı görülmektedir. Eski Türk devletlerinde töre kabul edilen tüm kuralların adalete uygun olması ve kağanlar da dâhil tüm toplumun töreye uyması zorunludur. Bu nedenle kağanlar kendilerini töreye uyma konusunda halka hesap verme yükümlülüğü altında görmüşlerdir. Türklerin İslâmiyet'i kabulünden sonra da kurdukları devletlerde töre hükümdarların egemenlik yetkilerinin sınırlanmasında rol oynamıştır (Pamir, 2009). Kutadgu Bilig'de de Küntogdı́dan bahsedilirken acı ot ve şeker temsili verilir. $\mathrm{Acl}$ ot zulüm ve haksızlık yapanlar içindir. Şeker ise adaleti devlet kapısında bulanlar içindir. Adaletin tesis edilmesinde yönetici sınıfının sorumluluğunun hem adaleti oluşturma hem de kendi oluşturduğu adaletin sınırları dışına çıkmama ve hesap verme olduğu söylenebilir. Bu bağlamda özellikle doğrudan devlet kadroları için yetiştirilen yönetici adaylarının eğitiminde Kutadgu Bilig'in kaynak kitap olarak kullanılabilirliği incelenebilir. 
Kutadgu Bilig'de hükümdarın kararlarını alırken bilge ve liyakat sahibi kişilere danışması gerektiği vurgulanmaktadır. Küntogdı, kararlarını alırken veziri Aytoldu'ya, Öğdilmiş ve Odgırmış’a danışır ve onların düşüncelerine önem verir. Eserde hükümdarın sorumluluklarını yardımcılarıyla paylaşması Türk devlet geleneğinde, devletin tek kişi tarafından yönetilmediği düşüncesini doğrulamaktadır. Demirel (2014) tarafından yapılan Kutadgu Bilig'de devlet yönetimine ilişkin makalenin sonuçları bu düşünceyi doğrulamaktadır. Dolayısıyla bu anlayışa göre günümüz yöneticilerinin yönetim becerilerini belirleyecekleri liyakat sahibi kişilerle birlikte şekillendirmeleri önerilebilir.

Kutadgu Bilig'de halkın maddî ve manevî refahını sağlamak, güvenli bir yaşam sunmak ve düzeni sağlamak devletin görevleri arasında zikredilmektedir. $\mathrm{Bu}$ yüzden devletin ordusunun güçlü olması ve hükümdarın ordusunu kumanda edebilecek yeterliliğe sahip olması ayrıca başarıları karşısında ordusunu ödüllendirmesi gerektiği vurgulanmaktadır.

Kutadgu Bilig'de bir hükümdarın cömert olması, mala tamah etmemesi ve malını dağıtması istenir. Ayrıca hükümdarın hiddetle karar vermemesi, cezalandıracağı zaman düşünmesi tavsiye edilir. Kurtlu ve Koçak (2016) çalışmalarında Oğuz Kağan Destanı́nı hükümdar tasarımı açısından incelemiş ve benzer sonuçlara ulaşmıştır. Çalışmada Oğuz Kağan'ın kağan olarak taşıdığı özelliklerin kaynağının Gök Tanrı'ya atfedildiği, asil bir soydan geldiği, zekâsı, bilgisi ve aklı, adaleti, doğruluğu, ihtiyatlı karar vermesi, cömertliği, merhameti, sabrı, ordusunun kuvveti, halkının refah ve mutluluğunu temin etmesi gibi özellikleri taşıdığı sembolik bir dille ifade edilmiştir. Buna göre tarih boyunca çeşitli dönemlerde yönetim ve siyaset konularının işlendiği eserler incelenerek tarihi seyir içinde Türk devlet geleneğinde devlet yönetim felsefesinde bir değişiklik yaşanıp yaşanmadığı ortaya çıkarılabilir. Bu, sosyologlar veya siyaset felsefesi alanında çalışan araştırmacılar için bir araştırma sorusu olabilir. 
Türk devlet ve hâkimiyet anlayışı dikkate alındığında Kutadgu Bilig'de vurgulanan hükümdar tipinin sahip olduğu özelliklerin aslında bir yöneticinin sahip olması beklenilen özellikler olduğu görülmektedir. Ancak yerleşik hayata geçilmesi ile birlikte bozkır tipi alp tipinin yerini daha sistematik bir devlet algısının aldığı görülmektedir. Yusuf Has Hâcib'in, devlet başkanının portresini çizerken, son derece ayrıntıya girmiş olduğu belirlenmiştir. Yusuf Has Hâcib’in aradığı bu kıstaslar evrenseldir ve bütün zamanlar için geçerlidir (Öz, 2011). Bu kıstaslardan hareketle Türklerin cihan hâkimiyeti gibi büyük bir ülküyü gerçekleştirecek devlet adamlarının da rastgele biri olamayacağı düşüncesi hem İslamiyet öncesinde hem de İslamiyet'in kabulünden sonra varlığını koruduğu sonucu çıkarılabilir. Bu sonuçlardan hareketle toplumsal yapıyı yansıtan birinin yönetici olabileceği bir yapıda, evrensel değerleri içeren yönetici nitelikleri eğitimin her kademesinde dil ve değer eğitiminde kullanılabilirliği sorgulanabilir. Kutadgu Bilig'in özellikle yönetim kademesinde bulunan kişiler için başucu kitabı olabileceği, bunun için de kitabın yönetici anlayışıyla ilgili bölümlerinin bir kitap halinde sunulabileceği düşünülmektedir. Yine eserde belirtilen bey niteliklerinin ve yönetim anlayışının günümüzde her hangi bir değişiklik gösterip göstermediği farklı bir araştırmanın nesnesi olabilir.

\section{KAYNAKÇA}

Açık, T. (2016). “Kutadgu Bilig'de Devlet Yönetimi." Kırıkkale Üniversitesi Sosyal Bilimler Dergisi, 6(1): 419-438.

Adalıŏlu, H. H. (2013). "Bir Siyasetname Olarak "Kutadgu Bilig." Selçuk Üniversitesi Türkiyat Araştırmaları Dergisi, 34: 237-253.

Akyüz, H. (2002). Kutadgu Bilig'de sosyo pedagojik ve siyasal söylem. Erzurum: Eser Ofset.

Aydınlı, Y. (2004). “Farabi'nin Bilgi Anlayışına Genel Bir Bakış.” Bilimname, 4(1): 5-16. 
Banarlı, N. S. (1987). Resimli Türk edebiyatı tarihi I-II. İstanbul: Milli Eğitim Bakanlığı Yayınları.

Banarlı, N. S. (2004). Resimli Türk edebiyâtı târihi. (I. Cilt). İstanbul: Milli Eğitim Bakanlığı Yayınları.

Büyükbaş, H. ve Vargün, F. (2016). “Kutadgu Bilig'de Devlet Yönetimi Hükümdar-Adalet İlişkisi." Ardahan Üniversitesi İktisadi ve İdari Bilimler Fakültesi Dergisi, 4: 27-33.

Caferoğlu, A. (2000). Türk dili tarihi I. Ankara: TDK Yayınları.

Demirel, D. (2014). “Kutadgu Bilig'de Devlet Yönetimi.” Uluslararası Alanya İşletme Fakültesi Dergisi, 6(1): 55-61.

Doğan, N. (2002). “Kutadgu Bilig'in Devlet Felsefesi." Sosyal Bilimler Enstitüsü Dergisi, (12): 127-158.

Ergin, M. (2011). Orhun Abideleri. İstanbul: Boğaziçi Yayınları.

Has Hâcib, Y. (1985). Kutadgu Bilig. Çev., Reşit Rahmeti Arat. Ankara: Türk Tarih Kurumu Basımevi.

İnan, A. (1970). "Yusuf Has Hâcib ve Eseri Kutadgu Bilig Üzerine Notlar." Türk Kültürü, 98: 112-126.

Kabaklı, A. (2006). Türk edebiyatı (II. Cilt). (Gözden Geçirilmiş 13. Baskı). İstanbul: Türk Edebiyatı Vakfı Yayınları.

Kafesoğlu, ì. (1980). Kutadgu Bilig ve kültür tarihimizdeki yeri. kültür Bakanlığı.

Kara, N. (2016). Fârâbî́de ideal insan. Yayımlanmamış yüksek lisans tezi, Ankara Üniversitesi Sosyal Bilimler Enstitüsü Felsefe ve Din Bilimleri (İslam Felsefesi) Anabilim Dalı, Ankara.

Karakaş, S. (1998). Türk Idare Tarihinde Hâkimiyet Anlayışı (Türkçe Kaynaklara Göre Başlangıcından XI. Yüzyılın Sonuna Kadar). Yayımlanmamış yüksek lisans tezi, Gazi Üniversitesi, Ankara.

Kaşgarlı Mahmut. (1991). Divanü Lügat-it Türk. Çev., Besim Atalay. Anakara: Türk Dil Kurumu Yayını. 
Kazmaz, S. (2000). Hukuk ve devlet yönetimi açısından Kutadgu Bilig. Ankara: Takav Matbaacılık.

Keskin, A. (2012). “Oğuz Kağan Destan Metninde Kahramanın Takdimi.” Millî Folklor, 24(96): 5-18.

Koca, S. (2002). Eski Türklerde Devlet Geleneği ve Teşkilatı, Türkler, c. 2. Yeni Türkiye Yayınları.

Kurtlu, Y. ve Koçak, B. (2016). “Oğuz Kağan Destanı'nda Hükümdar Tasarımı.” A. Ü. Türkiyat Araştırmaları Enstitüsü Dergisi [TAED], 56: 875-901.

Ögel, B. (1982). Türklerde devlet anlayışı. Ankara.

Öz, Ş. (2011). “Kutadgu Bilig'de Türk Cihan Hâkimiyeti Düşüncesi.” Dinbilimleri Akademik Araştırma Dergisi, 1(11): 19-35.

Özdemir, G. (2009). “Batı'da ve Türklerde Egemenlik Kavramı.” DPÜ SBE Dergisi, 23: 123-138.

Pamir, A. (2009). "Orta-Asya Türk Hukukunda "Töre" Kavramı." Ankara Üniversitesi Hukuk Fakültesi Dergisi, 58 (2): 359-375.

Sarıkaya, M. Z. (2014). “Kutadgu Bilig'e Göre Bey'in Özellikleri.” International Journal of Social Science, 30(1): 551-568.

Sinan Nizam, B. (2010). “Divan Şiirinin Alegorik Âşık ve Maşuklarından Gül ü Bülbül." Turkish Studies International Periodical For the Languages, Literature and History of Turkish or Turkic, 5(3): 462-478.

Tuğral, O. (2008). Kutadgu Bilig ve Siyasetname'de Devlet Anlayışı. Yayımlanmamış yüksek lisans tezi. Niğde Üniversitesi Sosyal Bilimler Enstitüsü, Niğde.

Turan, F.A. (2011). “Orta Asya'dan Anadolu'ya Mitik Yolculukta Tabiat Olayları.” Milli Folklor, 23 (90): 49-59. 


\section{EXTENDED ABSTRACT}

\section{Introduction}

Cultural accumulation in the process of transition from the society to the nation and to the statehood has important information in terms of its consequences as well as its preparatory effect. Verbal or written literary products are at the forefront of rich information sources of nations. Kutadgu Bilig, one of the first Turkish works after Islamism, is an eternal means for Turkish culture. It is possible to find social life, religion, thinking, government understanding, state philosophy and many other cultural codes of Turks.

\section{Method}

In this study, Kutadgu Bilig was examined in terms of the characteristics that a manager is expected to have in the context of "manager" and Turkish history and culture. In the study Kutadgu Bilig's sections XII, XVII, XVIII, XXI, XXIII, XXIV, $X X V, X X V I, X X V I I, X L I, X L I I$ and XLIII have been examined in terms of the design of the ruler and the understanding of the state. However, the other sections of the work were also utilized according to the subject discussed. Citations from the work have been included in the presentation of the manager features.

\section{Findings}

Hâcib first deals with his understanding of the 'kut' regarding the state administrator. According to the constitution God has created the man to be a governor, equipped with the talents he should have, and whose father is the governor is the governor himself. The work also includes the physical characteristics that a ruler (governor) should possess. Moderation emphasis is also important. According to the work, the ruler is depicted as a mediumheight, beautiful-faced man with clean-cut hair and beard. Also, one of the most important features that a governor should have, are to be intelligent and knowledgeable, which is expressed frequently in the work. Information is obtained with wisdom and information obtained using wisdom is put into practice. Therefore, the ruler must be intelligent and wise in order to be able to bring happiness and to fulfil the needs of his nation in both universes.

The ruler must not be cruel and miser, and should not spill blood for nothing. Moreover, while the ruler is implementing the laws, he should behave equally to everyone and should not tyrannize anyone while trying to achieve justice. It is expressed that the order is based on justice, that the law keeps the order alive, and that God provides the order on earth with the governors providing justice. 
One of the most important features of the Turkish rulers is to be brave, strong and heroic. Thus, the Turkish rulers do not give orders from where they sit, if necessary, go to war with his army, take part in the front line and battle. The ruler must be cautious and prudent and also has political knowledge to manage his country.

The ruler must be good in all situations and attitudes, and must speak the good, the governor must be straightforward and honest, keep to the straight and narrow and should not accredit lies, be intelligent and vigilant, be generous, should not desire possessions and know to thank what's been given to him. In addition, it is stated that while it is advised for him to be patient while reaching his desires, he should not be in a hurry in lavishing something to his people, and also, he should be patient about punishment. Also, a governor should not think about his own personal tendencies when practicing politics.

One of the important responsibilities of a governor is assign duty to those who are loyal, distinguished and efficient at every grade of the state for the continuity of the state and happiness. It is expressed that there must be helpers around the governors to facilitate their works. These intelligent and wise individuals help the ruler govern the state. According to this, the state is not governed by one person and domination is not dependent on one person. Another important duty of the ruler is to protect the scholars and to eliminate their troubles. Because scholars are the individuals who deliver the person to the state and happiness. In addition, the ruler is responsible for ensuring the state's order and for not letting the evils go unpunished.

In the Turkish state tradition, a khan or ruler is obliged to expand the borders of his country by conquering. When the Turkish history is examined, it is seen that the vast majority of the rulers who head the state spent their lives with conquests. In the eleventh century, with the adoption of Islam, the jihad thought is also seen in Turks. For this reason, it appears that Yusuf Has Hâcib charged the ruler with the task of jihad in Kutadgu Bilig. Thus, from the eleventh century onwards, the aim of spreading Islam is added to the universal dominance ideal of the Turks.

\section{Conclusion}

In the study, the type of the ruler depicted in Kutadgu Bilig is knowledgeable, powerful, warrior, makes his people happy by expanding the boundaries of his country by managing his state with the knowledge of politics. However, due to the acceptance of Islam in the Karahanlılar State, the influence of religion in the depictions of the ruler is observed. Considering the concept of Turkish state and sovereignty, it is seen that the features possessed by the ruler are in fact the 
expected characteristics that a ruler should have. However, with the adoption of a sedentary life in the Turks, it is seen that the steppe type and the alp type are replaced by a more systematic management approach. It seems that Yusuf Has Hâcib, while portraying the state manager, has gone into great detail. By acting on these criteria, the thought that the statesmen, who will realize a great ideal like the dominance of the world by of Turks and would not be a random person has kept its existence both before Islam and after the acceptance of Islam. 